\title{
The image of a Christian in Sidonius Apollinaris' letters
}

\author{
Elena Litovchenko ${ }^{1, *}$, Sergey Kutomanov $^{1}$, Marina Ryabtseva $^{1}$, and Inna Onoprienko ${ }^{1}$ \\ ${ }^{1}$ Belgorod National Research University, 308015, Belgorod, Russia
}

\begin{abstract}
The paper deals with the collective image of a Christian reconstructed by comparing several portraits described in the 5th century Gallo-Roman writer's epistles and verses Sidonius Apollinaris. This source was chosen due to the fact that Sidonius himself combined the features inherent for both the representative of the highest social stratum of the Late Antique society and for the Christian shepherd. The method of cultural and historical reconstruction with combination of biographical and retrospective methods is used for the formation of the image of a Christian of the Late Antiquity. The authors come to the conclusion that during the 5th century $\mathrm{AD}$ as a true Christian was deemed such person who observes the biblical commandments and church rites, distinguished by patience and mercy. The image of a Christian evolved in this period from the weakly expressed version presented by Germanicus, a man for whom, more important the ancient cult of the body, despite belonging to Christian flock, to the ideal, seeking to asceticism, who embodied the bishop Faustus.
\end{abstract}

\section{Introduction}

In contemporary society, which has lost its spiritual guidelines, consumership becomes the most common way to neutralize an existential hole in people's minds. However, this process cannot help us answer the eternal questions of being: Who are we? Where we are going? While in religion and philosophy answers are given and priorities are indicated. Therefore, the problems associated with faith, today more relevant than ever.

In the modern world, about a third of the world's population are Christians. We can designate a Christian as someone who adheres to Christianity, which is based on the life and teachings of Jesus Christ. A true Christian is a follower of Christ. They follow Him on the way of victory over sin, with the goal to attain divine nature and become holy as $\mathrm{He}$ is holy (Matthew 16:24; 1 Peter 1:15; 2 Peter 1:4). Subsequently, in his external representation the true Christian is usually a person who leads a righteous life, i.e. keeping biblical commandments, regularly attending Church services, performing ceremonies, distinguished by mercy towards the afflicted.

It is obvious that this image was formed over a long time. Today it is important for us to understand what milestones this image went through in its sociocultural development, how the role of the Christian was formed, which persons served as an example. Within this framework, we interested in not a canonical image (according to Scripture or the lives of

\footnotetext{
* Corresponding author: litovchenko@,bsu.edu.ru
} 
Saints) but in examples from ordinary, everyday life. This opportunity is provided by ego documents, like diaries or letters. We refer to the fifth-century author, the Gallo-Roman aristocrat and bishop, Sidonius Apollinaris (ca. 430-489).

The purpose of this study is to reconstruct the collective image of the Christian of the second half of the 5th century by comparing several portraits that can be found in the epistles and verses of Sidonius Apollinaris.

\section{Sources and methodology}

Sidonius Apollinaris, being a representative of the Late Roman nobility and a bishop, was an example of a Christian of a transitional period. The Late Antiquity is justly considered as such a conversion time [see, for example, 1, 2 et al.]. He combined the features of pagan culture (aristocratic upbringing, rhetorical education, service on the state, etc.) and Christian one (Scripture quotation, episcopal care for the flock, etc.). At the same time, Sidonius often focuses on the emotional and spiritual spheres, on the features of individual personalities in his letters. Thus, in relation to the topic of our research, the epistles of Sidonius Apollinaris contains the images of such Christians as: Germanicus, a Christian who leads way of life, which seems not too pious (Sid. Ep. IV.13) ${ }^{1}$; noble Vectius (Ibid. IV. 9), a Christian who has not occupied a position in the Church hierarchy, a priest Maximus (Ibid. IV. 24) [the full translation of this letter has done by E.V. Litovchenko, see 3] and bishop Faustus of Riez (Id. Carm. XVI). The letters and poetic lines in honor of Faustus were written between 461 and 472 . These images are in focus of our study due to the fact that Sidonius gives a complete description of them, including appearance, behavior pattern and some elements of everyday life. In addition, the analyzed figures represent different facets of the same social role - the Christian believer, and in two cases - a representative of the clergy, which allows us to vividly show two aspects of studying the social role: role expectation and role-playing in historical and cultural retrospective.

The methodological basis of our research is a combination of biographical and retrospective methods. The first helps us to analyze the data set on the figures of the past, on the way of their functioning in the social, political, economic, spiritual institutions of their time. It conduces to identifying different types of connections between people (in this aspect, the biographical method is close to prosopographical in the understanding of Catherine Keats-Rohan [4,5]. Applying the retrospective method, we come to a more accurate reconstruction of the image of the Christian of the Late Roman epoch and to an understanding of the causes that gave rise to some modern phenomena.

\section{Findings}

We deliberately arranged the characters of our study in a hierarchy based on the degree of strengthening of the Christian ardour. Therefore, the first object is the Germanicus, ${ }^{2}$ which is described by Sidonius in detail in a letter to Vectius (Sid. Ep. IV.13). Sidonius asks Vectius to convince his friend and neighbor Germanicus to change his life for more appropriate to the Christian. The author of the letter considers Germanicus as a man of fashion and youthy (repuerascit), contrary to his age, because his clothes and shoes fit the silhouette, hair trimmed in the shape of a wheel, and "...tweezers searched the depths of all his wrinkles to remove every hair from his face..." (Ibid. IV.13, 1). ${ }^{3}$

Sidonius does not say directly whether Germanicus is a Christian, however, with his father bishop, it is unlikely that another option is possible. Moreover, the author of the letter asks Vectius to persuade Germanicus to adopt the priestly dignity appropriate for he is the son of the bishop and the father of the priest (...nam sacerdotis pater filiusque pontificis, 
nisi sanctus est...) (IV. 13, 4). Sidonius finds convincing words, emphasizing that everything is transient, and what Germanicus has (first of all, his health) is given to him by the grace of God, therefore he must to repent of sins and through good deeds become a new person in his old age.

As for the other letter, it describes the already mentioned above Vectius, a nobleman (vir inlustris), the owner of a large country estate in Chanteheux (Auvergne), living in the world, but practicing austerity [6]. It shows an aristocrat who performs duties according to his position in society, but at the same time spending a lot of time reading the Holy Scriptures. Sidonius believes that Vectius household has off the immaculate purity of the life of its owner: "His hard-working servants ... are kind ... friendly, obedient and satisfied with their master. His table is open to a stranger no less than to his own clients; there prevails great hospitality and even greater moderation" (IV.9.1); “...he is not inclined to violence towards the servants, and he is not shy about accepting their advices $<\ldots>$ he can even be mistaken for a steward in his own house..." (IV.9.4).

Getting acquainted with the appearance and occupations of Vectius, we gain a completely familiar image of a Roman aristocrat: “...he has no superior in dressage horses, dog training or hawks; he is the height of elegance in clothes with a trig belt and in the shine of jewelry..." (IV.9.2); further Sidonius adds that, Vectius likes hunting not for the kill, but for the process, since he likes to indulge in the chase, and this is quite consistent with his religious feelings (IV.9.3). The latter are manifested in the fact that he "...is a regular reader of the Holy Scriptures; even while eating he enjoying this food for the soul. He studies psalms and increasingly repeats them; $<\ldots>$ he is a complete monk in everything except monastic vestments..." (Ibid.) Vectius is characterized as a caring father: "His consolation is a little daughter, the only pledge of love of his untimely departed wife; he educates her with the gentleness of grandfather, the diligent care of mother, the kindness of father..." (IV.9.4).

In conclusion, Sidonius holds up Vectius as an example not only to the laity, but also to the clergymen: "...for our century it would be good if every member of our sacred profession was inspired by this story...” (IV.9.5).

The content of the next letter is devoted to the priest Maximus. In this epistle Maximus appears for the creditor of Sidonius' friend Turpio. Sidonius applies with a delay in the payment of the debt by the children of Turpio, due to the illness of their father. Maximus was also an old friend and neighbor of Sidonius, his estate was located somewhere between Clermont and Toulouse [6]. He was a former servant of the imperial court (palatinus), was ordained, although he did not have much desire for this (IV.24, 4).

Sidonius had not seen Maximus for a long time and was amazed at the changes that had happened to him: “...how his gait has varied: there was not a trace of his former bearing; and how his voice has changed! His clothes, humility; his pallor, manner of speech, everything represented the priest in him. His hair was cut short and his beard was long..." (IV.24, 3). The author of the letter paid attention to the surroundings: “...there were simple tripod chairs in the house, and instead of the door there was a thick curtain covering; the beds are hard, the tables are bare. His treat consisted of more fruit than meat and looked like vegetarian; and if a richer dish appeared, it was intended for the guests, not for himself ... " (Ibid.) Maximus complied with Sidonius' request and agreed to pay the debt without interest, for which he was awarded the title of "merciful soul", which is "worthy for Kingdom of Heaven" (IV.24, 6-7).

It is interesting that, both in the characteristics of Maximus and Vectius, the social component, which was mandatory for any representative of the nobility at the end of the 4th - the beginning of the 5th centuries, is completely absent. In the letters of the pagan Symmachus, honorary positions are regarded as something to be proud of (Symm. Ep. 16), and public affairs must be combined with literary activity (Ibid. 18), since it is the true 
virtues of the upper class. We know, that Sidonius himself quite often urges his kith to "throw a hoe" and serve the public good (see, for example, Sid. Ep. I. 6). The interests of man are almost closed on his small private world, limited by his possessions. In addition, there is not a single word in these letters about the level of education of the objects of Sidonius' attention; nothing is said about their eloquence or literary activities that the Late Antique writer himself considered as a marker of nobility's identity. Apparently, the accentuation of traits valued by Christian morality overshadowed the classical attitudes in this particular case.

This thesis can be confirmed by the example of the characteristics that Sidonius gives to Faustus of Riez, bishop in Southern Gaul. Sidonius describes the bishop with the most enthusiastic and reverent feelings. First of all, in very allegorical expressions, he admires his penchant for austerity, moderation in food: “...you almost do not eat cooked food in your abstinence..." (Carm. XVI. 100). It further speaks of the important edifying role “...you serve as a mentor to everyone, forgetting about rest and sleep..." (Ibid.).

By his example he inspires the flock: "...the people entrusted to you ... dare, when you are with them, to resist even the strongest..." (XVI. 110). He eases the sufferings of the hungry, the sick, the prisoners: "...you watch anxiously with what food the sick eats ... how one who languishes in prison quenches thirst and hunger ... the remains of the poverty stricken dead ... you carry into the grave yourself without shunning ... (XVI. 118 -123) [Transl. by F.A. Petrovskij, see 7].

Obviously, the portrait of Faustus is the quintessence of Christian virtue, the embodiment of spiritual perfection, as befits a bishop.

\section{Conclusion}

Thus, on the material of the works of Sidonius we can reveal several versions of the image of the Christian in the 5th century AD: from Germanicus, a person who actually neglects the rules of Christian morality and supports the ancient body cult, to bishop Faustus as the focus of Christian virtues. At the same time, the figure of Vectius can be regarded as a kind of intermediate version of the believer, in whose image typical antique features play a very important role: the ability to manage the household, the presence of clients, hospitality, and elegant appearance. As the features distinguishing a true Christian, Sidonius considered: moderation, both in food and in life in whole, reading sacred texts, meekness, mercy, devoting himself to serving God and the flock, as we see from the example of priest Maximus and bishop Faustus. The latter model enshrines the key attributes of the Christian image (role expectation). The characteristics of various representatives of Sidonius' social environment provide examples of the role of the Christian believer.

We suppose the further research activity from this perspective would be linked with adding another Christians, which Sidonius mentions. This will lead to more complete understanding of image of a Christian of the 5th century. In addition, it may be reasonable to expand the chronological frames to 6th centuries, by way of involvement the information of other Late Antique sources such as letters of Ruricius of Limoges, Avitus of Vienne, Ennodius et al.

\section{Note}

1. Numeration is given by edition: Sidonii Apollinaris Epistularum Libri I-IX // The Latin Library. The Classics Page. The Miscellany. URL: http://www.thelatinlibrary.com/sidonius.html. Sidonius' written-text translation has done 
by O.M. Dalton in 1915 and W.B. Anderson in 1936 (books 1-2). The dateline see in the list of references.

2. Germanicus - vir spectabilis ("highborn man, honest man", the second senatorial title in the Late Roman Empire and Early Byzantium) at the age of 60, his father was a bishop, his son was a priest (Martindale, 1980, p. 504).

3. Here and further transl. by authors.

\section{Sources}

Sidonii Apollinaris Epistularum Libri I-IX in The Latin Library. The Classics Page. The Miscellany. URL: http://www.thelatinlibrary.com/sidonius.html.

Q. Aurelii Symmachi quae supersunt (1883). Ed. O. Seek (355 p.) in Monumenta Germaniae Historica. Auctorum Antiquissimorum. T.6. Symmachi opera. Berlin: Weidmannos.

\section{Translations}

The Letters of Sidonius, translated, with introduction and notes by Dalton O.M. (1915). 2 vols. Oxford. Online ed. R. Pearse, 2003. - Pp. xi-clv; Introduction. - URL: http://www.ccel.org/p/pearse/morefathers/sidonius_letters_00_4_biblio/

Sidonius. Poems. Letters: Books 1-2 (1936) Translate $\overline{-} \bar{b}$ W.B. Anderson. Loeb Classical Library 296. Cambridge, MA: Harvard University Press, URL: https://www.loebclassics.com/view/sidonius-letters/1936/pb_LCL296.399.xml.

\section{References}

1. P. Brown, The World of Late Antiquity. AD 150-750 (Thames \& Hudson Ltd, London, 1989)

2. N.N. Bolgov, Late Antiquity: New methodological approaches to transitional historical era, Network scientific journal, Social studies and Humanities, 4(6), (2015)

3. E.V. Litovchenko, Sidonius Apollinaris. The letter to his friend Turnus, Collection of papers of the Faculty of Philisophy of the University of Pristina, 46(2), (2016)

4. K.S.B. Keats-Rohan, Prosopography and Computing: A Marriage Made in Heaven?, History and Computing, 12(1), (2000)

5. K.S.B. Keats-Rohan, Prosopography Approaches and Applications: A handbook (Oxford University Press, Oxford, 2007)

6. J.R. Martindale, The Prosopography of the Later Roman Empire. V. II. AD. 395-527. (Cambridge University Press, Cambridge, 1980)

7. F.A. Petrovskij, Thanksgiving to Bishop Faustus, Monuments of medieval literature from Fourth to Seventh centuries (Heritage, Moscow, 1998) 